\title{
A Memory of Concrete: Politics of Representation and Silence in the Agostinho Neto Memorial
}

\author{
VASCO MARTINS AND MIGUEL CARDINA ${ }^{1}$ \\ CES-UC \\ https://orcid.org/0000-0001-6205-4053 https://orcid.org/0000-0001-5428-457X
}

\begin{abstract}
Focusing on the Memorial António Agostinho Neto (MAAN) in Angola as the case study to analyse materialisations of memory, the article attempts to read the political representations of this monument by analysing its main narratives, questioning its silences and unpacking its impact on public memory. To do so, the article is divided into three parts. The first section engages with the relevant academic literature on southern African memorialisation and provides a brief description of the MAAN. The second and third sections consider Richard Werbner's notion of elite memorialism to produce a two-dimensional analysis, referencing the absence of MPLA narrative and symbols in the MAAN while noting how it became inaccessible to the ordinary Angolan population, a result of more ample dynamics of state society relations in the country. It concludes that the logics of social hierarchy that have promoted the marginalisation of segments of the population have impacted the MAAN's ability to contribute to the new ways Angolans are imagining the nation.
\end{abstract}

\section{Introduction}

'Eternal glory to our heroes' was one of the last sentences Agostinho Neto proffered during his speech to declare the independence of Angola. But which heroes were to bask in this eternal glory? Would all Angolans be included, only MPLA ${ }^{2}$ heroes or only those within Agostinho Neto's ${ }^{3}$ faction in the MPLA? The history of the Angolan liberation struggle had already made clear that celebrations would entail political problems. Angola's liberation struggle became divided between three

1 The research leading to these results has received funding from the European Research Council (ERC) under the European Union's Horizon 2020 research and innovation programme (Grant Agreement No 715593: 'CROME - Crossed Memories, Politics of Silence: The Colonial-Liberation Wars in Postcolonial Times'). The authors would like to thank the Administration of the MAAN and particularly the Director of the Department of the Sarcophagus, Mr. Rigoberto Fialho, for the support and the kind availability demonstrated throughout the research of this article as well as two anonymous reviewers for their remarks on the initial manuscript.

2 Movimento Popular de Libertação de Angola, the Popular Movement for the Liberation of Angola.

3 António Agostinho Neto was a historical Angolan nationalist who became the president of the MPLA in 1962 and the first President of the Popular Republic of Angola in 1975. It was Neto who declared the country's independence from Portugal on the 11 November 1975. 
liberation movements, ${ }^{4}$ each pushing their own vision of the nation, their particular narratives and historical points of identity. But not only divisions between liberation movements became problematic for remembrance; the ruling MPLA also went through grave problems of dissidence and leadership contestation, frequently involved in internal division and conflict. The effects these specificities of Angolan anti-colonial nationalism would produce in the processes of memorialisation during the post-independence period, in addition to the 27 years of civil war that only ended in 2002, would come to touch the very essence of the national project in Angola.

Public debates about the liberation struggle in Angola revolve around issues of national holidays and commemorative dates. Most visibly, they touch upon monuments and heroes, producing conversations about representation of those who are celebrated and silence of those who have been marginalised. This article attempts to engage in a debate that has yet to initiate an academic conversation by looking at one specific monument in Angola dedicated to the memory of Angolas first President, António Agostinho Neto, the Memorial António Agostinho Neto (MAAN). Following the hypothesis that the MAAN works as a sacred ground for the birth of the Angolan nation, the place where all Angolans see honouring their identity and nationality, the article attempts to identify and unpack issues of political representation and silence in the monument. It posits the MAAN within the dynamics of memorialisation and monumentalisation in the southern African region by adopting Richard Werbner's notion of elite memorialism as a conceptual compass. It is through this conceptual approach that the ruling party's political conflicts, nationalist divisions and postcolonial state society relations in the MAAN can be read.

The article is organised into three sections. The first section briefly characterises the MAAN and discusses Werbner's concept of elite memorialism in southern African literature while inserting Angola's historical dynamics in this conversation. It reads the MPLA's and Angola's history to note how the narrative provided in the MAAN presents not one but two dimensions of elite memorialism - an historical controversy of dissidence and conflict within the MPLA elite and a more ample division between the elites and the povo (the 'people', in Portuguese, referring to ordinary citizens). The second and third sections focus on demonstrating and unpacking these two dimensions. The second section explores what the authors consider to be the sidelining of the MPLA in the MAAN, of its most prominent leaders and historical figures, its symbols and narratives. It shows how the MAAN projects Neto as a solitary figure, supported by ambiguous representations of the povo yet deprived of his closest political allies, a representation that empties Neto's political growth and dedication to the party he led and helped to build. This notion is followed by a discussion of two aspects that have shaped the MAAN's narrative about the MPLA - the constant problems of internal dissidence and the changes in the political economy of

The Angolan liberation war was fought by the UPA/FNLA (União das Populações de Angola/Frente Nacional de Libertação de Angola), the MPLA and UNITA (União Nacional para a Independência Total de Angola) against the Portuguese colonial state between 1961 and 1975. 
the regime after Neto's death. The third section broadens the scope by looking at the impact the MAAN produces in Angolan public memory. It analyses and critiques the monument's impact on social memory by showing how it is not immune to the logics of social hierarchy and marginalisation that have contaminated public and private spaces in Angola, consequently excluding itself from contributing to the new ways Angolans are imagining the nation, something the MAAN clearly intended to do.

Research for this article entailed three fieldwork trips to Angola in October 2018, March and August 2019. The authors made four ethnographic guided visits to the monument and engaged in several nonrecorded conversations with tour guides and other working personnel about the representations and silences in the MAAN. Fieldwork produced two semi-structured recorded interviews and allowed for the collecting of newspaper articles and various other informative materials produced by the MAAN. It also entailed meetings with the administration of the MAAN and the FAAN (the António Agostinho Neto Foundation).

\section{The MAAN and southern African monumentalisation logics}

Monumentalisation in the southern African region, as Richard Werbner points out, is trapped in a postcolonial memorial complex, a form of situating memory and producing monuments designed in the west after the First World War. This modern form of memorialism received from western nation-states by African countries, when reworked to fit postcolonial settings, became remarkably fragile in the realisation of its performance. ${ }^{5}$ The model is fraught with controversies over 'site, design and financing' and 'the negotiation of local and national claims' to memory. ${ }^{6}$ Werbner argues that these novel forms of memorialism were in fact sponsoring what he terms elite memorialism in postcolonial southern Africa. ${ }^{7}$ Elite memorialism flags issues of inclusion and representation, whether they are influenced by class or gender or are politically, regionally or ethnically related, frequently promoting the role of struggle heroes while subordinating local and rural experiences and histories to national and urban dimensions.

Werbner finds various tensions between common citizenship and elite differentiation, between state and kin community and between government and ruling party, when unpacking the dynamics of representation reproduced in Zimbabwe's Heroes' Acre ${ }^{8}$, the monument that has set the model for such types of commemorative monumentalisation in the southern African region. ${ }^{9}$ Marschall observes that while

R. Werbner, 'Introduction, Beyond Oblivion: Confronting Memory Crisis' in R. Werbner (ed), Memory and the Postcolony: African Anthropology and the Critique of Power (London: Zed Books, 1998), 8.

6 D. J. Sherman, 'Art, Commerce, and the Production of Memory in France after World War 1' in J. R. Gillis (ed), Commemorations: the Politics of National Identity (New Jersey: Princeton University Press, 1994), 188.

7 Werbner, 'Introduction', 8.

8 Werbner, 'Smoke from the Barrel of a Gun: Postwars of the Dead, Memory and Reinscription in Zimbabwe' in R. Werbner (ed), Memory and the Postcolony: African Anthropology and the Critique of Power (London: Zed Books, 1998), 71-100. See also N. Kriger, 'From Patriotic Memories to "Patriotic History" in Zimbabwe, 1990-2005', Third World Quarterly, 27, 6, 2006, 1155-1158; T. Ranger, 'Nationalist Historiography, Patriotic History and the History of the Nation: the Struggle over the Past in Zimbabwe', Journal of Southern African Studies, 30, 2, June 2004.

9 S. Marschall, 'Commemorating "Struggle Heroes": Constructing a Genealogy for the New South Africa', International Journal of Heritage Studies, 12, 2, March 2006, 179. 
oscillating between the Zimbabwean elitist model of memorialisation and rejecting it in favour of broader definitions and more inclusive selection processes, the South African state's desire to promote reconciliation and nation building may lead to 'serious distortions and omissions. ${ }^{10}$ This is noticeable when the memory of dissent and violence between groups is suppressed in favour of a sense of unity, or when conflict over ownership of key events by different actors emerges. ${ }^{11}$ Rassool is clear in stating that although chief modes of reading the South African nation and how these take shape in heritage constructions and public culture have begun to crystallise, 'almost every sphere of heritage production has seen complexity, controversy and contestation. ${ }^{12}$ Heritage, he continues remains a 'highly contested arena' in South Africa. ${ }^{13}$ Looking at the Heroes' Acre monument in Windhoek, much like its counterpart in Zimbabwe, Becker also notes tensions, namely between the fallen heroes and heroines who led Namibia's struggle from exile and the Namibian people's role during the liberation struggle, who complain that 'Heroes' Acre was for Swapo Heroes only. ${ }^{14}$ Melber speaks about this exclusivist tendency, finding similarities with Zimbabwe while defining Namibian nation building in terms of marginalising the other as the enemy. ${ }^{15}$ Analysing the case of Mozambique, Albino Jopela also finds the ruling party Frelimo (Mozambican Liberation Front) focusing its memorialisation efforts on the liberation war, predominantly the struggle heroes, noting how this particular politics of representation and memorialisation has been contested, either by invoking silenced figures such as Uria Simango or actively by former combatants who still live today. ${ }^{16}$

Many southern African countries have in various albeit nuanced ways fashioned elite memorialism out of their monumentalisation of the liberation struggle. While Angola does not have one all-encompassing monument generically dedicated to the liberation struggle ${ }^{17}$, it does not escape the southern African tendency of elite memorialisation in its by far biggest monument, the MAAN. However, the historical narratives provided by the monument hold not one but two dimensions of elite memorialism. If within its halls the MPLA elite is hierarchically organised and one single political tendency among the many that define the party is presented as exclusive, from the outside the MAAN speaks to broader relations between state and society, between the elite and the popular masses. Two historical motives stand out as prime reasons for this dual dimension in elite memorialisation. First, as a site of memory that voices the cosmology of power of the MPLA but particularises Angola's first

\footnotetext{
Marschall, 'Commemorating', 180.

Marschall, ‘Commemorating', 182.

2 C. Rassool, 'The Rise of Heritage and the Construction of History in South Africa', Kronos: Journal of Cape History, 26, 1, January 2000, 1.

13 Rassool, 'The Rise of Heritage', 17.

14 H. Becker, 'Commemorating Heroes in Windhoek and Eenhana: Memory, Culture and Nationalism in Namibia, 1990-2010', Africa: Journal of the International African Institute, 81, 4, November 2011, 529.

15 H. Melber, 'Namibia, Land of the Brave: Selective Memories on War and Violence within Nation Building' in G. J. Abbink, M. de Brujin and K. V. Walraven (eds), Rethinking Resistance: Revolt and Violence in African History (Leiden: Brill, 2003$), 326$.

16 A. Jopela, 'The Politics of Liberation Heritage in Postcolonial Southern Africa with Special Reference to Mozambique' (D.Phil. thesis, University of Witwatersrand, 2017), 259-298.

17 The Angolan state built one monument dedicated to the soldiers that fought in all Angolan wars. That generically includes all the precolonial, anticolonial and civil wars.
} 
president Agostinho Neto, the MAAN speaks to a specific strand within the various political divisions that characterise the history of the MPLA. This liberation movement that became a ruling party after independence was often entrenched in internal quarrelling and leadership contestation. Splinter groups like the Revolta de Leste or the Revolta Activa presented significant challenges to Neto's rule: defections were not uncommon (most notably that of Daniel Chipenda to the bitter rival the FNLA), recurring disputes between Neto and Viriato da Cruz and Mário Pinto de Andrade, the MPLA's secretary-general and first president respectively, the killing of well-known cadres like Matias Migueis and the massive purge in response to the fraccionismo of 27 May 1977, are some of the lingering divisions within the MPLA. These historical events were read as political and ideological deviations that allowed the 'sacrosanct defence of unity inside the MPLA', meaning the authority of Neto's 'presidential tendency', in order to silence any plans of internal contestation and dissention. ${ }^{18}$

The edification of the postcolonial MPLA regime, and thus its partisan construction of Angolan history, had to deal with deep and frequently bloody division, often running through political, regional, ethnic, race and class issues. The question of how or who to commemorate was so profoundly divisive that its answer became unequivocal: precisely due to Neto's longstanding centralisation of power on the presidency, only Angola's first president Agostinho Neto could possibly be celebrated. A second historical particularity has to do with the existence of different strands of Angolan nationalism. The Angolan liberation movement had not one but three liberation movements vying for the independence of the country from Portuguese colonialism. Each had their own vision for the post-independence state, ideological alignments, international allies, cultural practices and regional basis of support. ${ }^{19}$ But the 27 year civil war that rapidly ensued after independence among the three liberation movements left many of the controversial aspects of the division of Angolan nationalism to be fought over in the battlefields of this war. This political and military context not only impeded monumentalisation projects, both politically and financially, but most importantly never allowed a public discussion on interpretation, narrative and representation. Adding to the traumatic and premature death of Neto in 1979, the MPLA government's solution was a partisan nation building monument that would force unification around his memory through the sacralisation of his life and the silencing of his internal and external enemies. The result was the construction of the biggest monument to a person in Angola, and one of the biggest in the world, the Memorial António Agostinho Neto in Luanda.

The cornerstone of the MAAN was laid on 17 September 1982 by former president José Eduardo dos Santos (JES) on the $60^{\text {th }}$ birthday of the by then deceased

J.M. Mabeko-Tali, Guerrilhas e Lutas Sociais: O MPLA Perante Si Próprio (1960-1977) (Lisboa: Mercado de Letras Editores, 2018), 633-34.

19 See C. Messiant, L'Angola Postcolonial 1. Guerre et Paix sans Democratisation (Paris: Éditions KARTHALA, 2008); J. Marcum, The Angolan Revolution Volume 1: The Anatomy of an Explosion (1950-1962) (Cambridge: The M.I.T. Press, 1969); F. Reis, Era uma vez... O Campo Político Angolano (1950-1965) (Luanda: Edições Mulemba, 2018); A. Malaquias, Rebels and Robbers: Violence in Post-Colonial Angola (Stockholm: Mordiska Afrikainstitutet, 2007). See also the documentary Independência, directed by Mário Bastos, produced by Paulo Lara and Jorge Cohen, with historian Mária Conceição Neto as consultant. The film avoids a typical format centred on the history of the MPLA and shows a balanced reading of the history of the Angolan liberation struggle, proposing consensus and including the contribution of all three Angolan liberation movements. 
Agostinho Neto. The monument was, according to JES's speech that day, 'to allow the current and next generation to honour and pay homage to his [Neto's] example which is always alive. ${ }^{20}$ To initiate the process of memorialisation, the Angolan government contracted the services of the Soviet Institute for Projects to build a mausoleum to accommodate the remains of President Neto. The contract 84/62808 of 14 June 1980 was signed between the People's Republic of Angola through the Ministry of Public Works (MINOPU) and the Soviet Institute for Projects. ${ }^{21}$ But exactly when construction started and when it stopped remains murky. Sometime between 1982 and 1986/87 the base of the memorial, the sarcophagus room and the tower were built. All information materials produced by the MAAN point to the political-military situation the country was facing to explain the halting of construction. This probably refers to the MPLA government's largest military action against UNITA and apartheid South Africa's invasions in the south of Angola, which resulted in the battle of Cuito Cuanavale, between 1987 and 1988, and led to the New York Accords later that year. It is probably the reason why construction was halted in 1988, after which the project came to be entirely reformed only in 1998, mainly to build a memorial instead of just a mausoleum.

With the project redesigned in 1998, construction resumed in 2005, three years after the end of the Angolan civil war and during a wave of national reconstruction. If in its conception the monument had at first the contribution of the Soviet Union, the project's completion came to be awarded to a North Korean company, the Mansudae Overseas Project (MOP), which gave a North Korean style of embellishment to socialist realism aesthetics. The monument's silent yet robust straight lines of grey concrete adorned with the emblem of the Angolan flag and a five-pointed star, symbols of progress within the socialist realism framework, looks like a spaceship, a rocket, o foguetão, the name that has popularly been used by Angolans (see Figure 1).

With 120 metres of height and a large base that funnels toward a single point in the sky, the monument's tower can be spotted from various points of downtown Luanda, most visibly near the Nova Marginal, the new marginal, in an area called Praia do Bispo. The information materials available state the designer of the MAAN was inspired by Neto's poem 'The pathway to the stars.'2 The rocket itself represents motion, lift-off; it points to the sky elevating Agostinho Neto and his memory above the nation. Its exterior sobriety contrasts with the 'airport-like interiors' and the 'Dubai-like design of the surrounding area', revealing 'shifting paradigms between the early independent government and the current one..23 The architecture of the MAAN

20 Discurso proferido pelo camarada Presidente José Eduardo dos Santos, em 17 de Setembro 1982, por ocasião do lançamento da $1^{\text {a }}$ pedra para a construção do mausoléu do saudoso Presidente Agostinho Neto. Speech by comrade President José Eduardo dos Santos, on 17 September 1982, on the occasion of the setting of the cornerstone for the construction of the mausoleum for President Agostinho Neto. Pamphlet of the speech available at the library of Associação Tchiweka de Documentação.

21 The history section at the MAAN website states the memorial was ordered to the Instituto de Projectos da Antiga URSS, the Institute of Projects of the former Soviet Union, while the leaflet available at the memorial states 'the structure was designed by a Russian company'. Both do not provide more information on this institute than this.

22 O caminho das estrelas, poem by António Agostinho Neto.

23 N. Siegert, 'Art Topples Monuments: Artistic Practice and Colonial/Postcolonial relations in the Public Space of Luanda', Portuguese Literary \& Cultural Studies, 30/31, 2018, 155. 


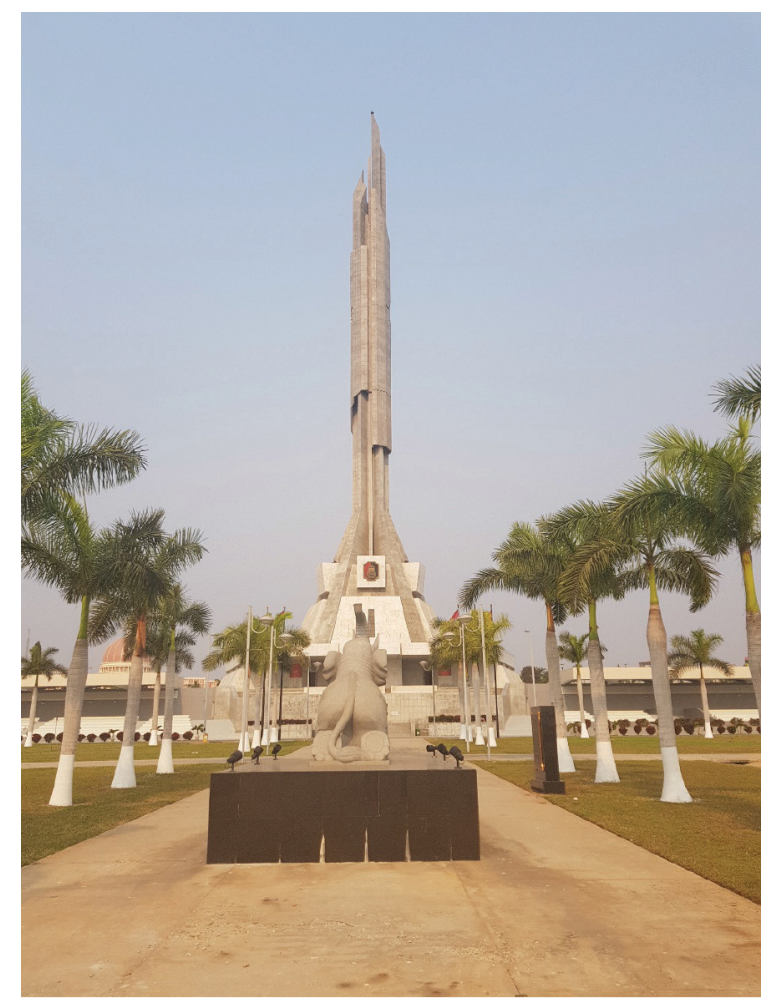

Figure 1: Aspect of the 'rocket-like' shape of the MAAN with an elephant representing the natural world paying homage to Agostinho Neto (Photograph by Miguel Cardina - CROME)

is clear in signalling the political alliances of post-independent Angola. Meghan Kirkwood considers that the contracting of the North Koreans and their visual culture represents an 'assertion of the authority and modernity by postcolonial regimes', which allows the inscription of new states in postcolonial narratives that symbolically break with their colonial antecedents. ${ }^{24}$ Yet, most importantly, these monuments possess codifications meant for internal consumption that fall upon political definitions of everlasting remembrance and glorification. As argued by David Lowenthal, 'memorials attest the desire to leave permanent physical witnesses. ${ }^{25}$ They are political bodies through which the dynamics of space, memory and power intersect, logics that are indispensable in the design of new sociopolitical orders. As such, they are privileged observatories to supervise the mobilisation of the past as a form of legitimising dominant powers.

The MAAN does allow the supervision of important aspects of the Angolan past. By the time it was complete, it opened to a very different public in a very different 
country from the one that first idealised Neto's resting place. Throughout its many years the construction of the MAAN became intimately connected to Angola's life, its ideological alignments and partnerships, its wars and political shifts. Its exterior appearance and interior halls provide clues that reflect the political struggles, controversies and taboos of postcolonial Angola. As is demonstrated in the next section, the MAAN stands as an open critique for elements of Angolan politics that have defined the recent history of the country.

\section{Agostinho Neto, the MPLA and the MAAN}

Imposing upon the Luanda cityscape, the MAAN offers a narrative of the history of the liberation struggle, of the nation and specifically of its most preeminent constructor and founder, Agostinho Neto. Its function resides in fixing a particular narrative of foundation, leadership and vision, a framework of origin and legitimacy. As Sabine Marschall explains, the function of monuments and memorials is not to preserve the memory of the past but to promote a particular interpretation. By selecting some memories while suppressing others, memorials seek to forge a particular historical consciousness and endorse the public remembrance of a person in a manner that will serve the ideology and political identity of its initiators. ${ }^{26}$ The MAAN was imagined and built to reflect one of the largest mnemonic monumentalisations of a person, its size uncommon in most parts of the world. It is filled with symbolic aspects that contribute to fix that exact narrative of independent Angola around a person as complex and as historically embedded as Neto.

One of the most striking features of the MAAN is how it deals with the various facets and long political career of Agostinho Neto. JES's speech in 1982 already contained the clues for the many and varied narrations the MAAN would come to expose: from the immortal guide of the Angolan Revolution, the founder of the nation and the MPLA-PT, but also to the poet, the liberator and, more markedly than the others, the providential statesman. An informative plaque at the museum section contains a citation from Carlos Brito, writer and militant of the Portuguese Communist Party, which reads:

Agostinho Neto was always one of the African leaders better known and more respected by the Portuguese people, and more appreciated and esteemed by the democratic and progressive sectors of Portugal. To that, it may have contributed the fact of [Neto] reuniting in the same person the revolutionary militant, the statist, the doctor, the poet and the man of culture. But it certainly contributed to his overflowing humanism [humanismo transbordante]. ${ }^{27}$ 
The largest section of the MAAN, its museum, is dedicated to these four mnemonic themes commonly associated with Agostinho Neto: the poet, the healer, the liberator and the statesman. Corridors all over the building are filled with passages of some of Neto's most well-known poems, depicting a man of culture and the arts, the man whose artistic sensibilities and poetic works illustrate the intellectual who came to be the first president of Angola. They imprint a sensibility for people, culture, land and, most importantly, a vision for the future of Angola. The healer theme is also present, although on a smaller scale, as it is presented amidst Neto as a student in Portugal and finally before his arrest in Luanda in 1960 where he was practising as a medical doctor in the Bairro Operário. But the most prevalent themes are certainly that of the liberator and statesman, the two characteristics that defined the political life of Agostinho Neto. There are pictures of Neto in the macquis with MPLA fighters, with a Kalashnikov rifle on his shoulder accompanied by guerrilla fighters in the background, several of Neto in the liberated areas during meetings and some of him posing with Portuguese army officials after signing the ceasefire. There is also information of his arrest by the Portuguese International and State Defence Police (PIDE), copies of his file and fingerprints and a detailed explanation of his escape from Portugal by boat under the title 'An astute escape', Uma fuga astuciosa. But above all other themes the MAAN celebrates Neto the statesman, the president who had the support of the people and governed for the people, the one who understood their dilemmas and anxieties. Passages of his famous sayings, 'O importante é resolver os problemas do povo' ${ }^{28}$ or 'eu não espero, sou aquele por quem se espera' ${ }^{29}$, from the poem 'Farewell at the time of parting', posit Neto as the person destined to become the leader of the Angolan people. It is a subordination of the Angolan nation to its greatest liberator and first president. This is assisted by products of memory showing Neto exercising the presidency of Angola: presidential photographs with various other state leaders, his several medals and honours presented by other countries, his suits, suitcases and a fully furnished office with a large painting of Neto in the centre and a representation of the Angolan people around him adorned with the Angolan flag on the bottom right side.

However, within the MAAN resides a most conspicuous deafening silence - the unambiguous sidelining of the MPLA. Prevailing internal divisions within the MPLA and the fragmentations of Angolan nationalism resonate through the rhetoric of the MAAN. If from the outside, it is understood as a symbol of MPLA supremacy by the Angolan population, within its halls it asserts the silence of the party in favour of the total hegemony, centrality and sacralisation of one man above everything else, Agostinho Neto. Two elements have historically contributed to the sidelining of the MPLA in the memorial: the constant problematics of internal dissidence and the paradigm change within the regime after Neto's death. Through the silencing of many of his internal opponents, Neto created a trusted inner circle that politically gravitated around him and continually asserted the dominance of the presidential tendency. 
This presidential tendency became mostly undisputed following the MPLA's InterRegional Conference of Militants between 12 and 20 September 1974 and the signing of the ceasefire with the Portuguese authorities on 21 October $1974 .{ }^{30}$ Still, only after the attempted 27 May 1977 coup would the MPLA's 'policy of exclusion and repression ... also affect those who dissented. ${ }^{31}$ After this traumatic event Neto had enough support to discredit any dispute to his role as supreme leader.

In the MAAN the crystallisation of Neto's hegemony as the undisputed leader is presented both as active memorialisation and as marginalisation of political difference and dissidence. By avoiding the history of contestation and defiance within the MPLA, the MAAN erased a distinctive part of Neto's struggle and growth as a political leader, opting to show no official interpretation of this part of Angolan history. Yet, it is imperative to note that many of the people who came to break away from Neto and are not represented in the MAAN had been well-known militants and heroes of the MPLA. Leaders like Viriato da Cruz, Mário Pinto de Andrade, Daniel Chipenda, Nito Alves or Monstro Imortal were central figures in the MPLA. ${ }^{32}$ Some like Daniel Chipenda and Nito Alves commanded such popular support that not only shadowed Neto's rule but contested it directly. By opting to exclude many of the MPLA's most visible cadres when following this historically limited and incomplete point of representation, the MAAN deprived itself of a vital articulation to an overarching theme of Angolan nationalism - the role of the MPLA in the liberation of Angola from Portuguese colonialism. The story of the movement's foundation, its diplomatic initiatives, first military operations and its most visible faces are absent in the memorial, apart from very few photographs that show Neto alongside central MPLA leaders like Américo Boavida, Iko Carreira and to a lesser degree Lúcio Lara. By depicting Neto not only as key in the MPLA's struggle against colonialism but mostly alone, this representation ignores that it was the MPLA, its leaders and cadres that at different points in history contributed to raise Agostinho Neto to the presidency of Angola.

More than historical ambiguity, the MAAN is also visibly missing in MPLA symbols. From what the authors could gather, only in a small room adjacent to the area where Neto's office, medals and honours are exhibited can an MPLA symbol be found, the party's flag. Yet, this particular flag, the one Agostinho Neto had in his office, stands as a paradigm of how political representation and symbolic adaptation evolve through time. If it is obvious that Neto was devoted to the movement and party he led and helped to build from 1962 until his death in 1979, why is the MPLA so invisible in the MAAN representations, particularly given the party's centrality in public life? When asked about this vacuum one of the guides stated that the MPLA is not very present because Neto is above the MPLA, as he was the president of all Angolans and not just of the party, but also a humanist, a poet and head of family. Indeed, Neto was already a well-known nationalist before assuming the presidency

30 Mabeko-Tali, 'Guerrilhas e Lutas Sociais', 318-319.

31 C. Messiant, 'The Mutation of Hegemonic Domination' in P. Chabal and N. Vidal (eds), Angola, the Weight of History (London: Hurst Publishers Ltd., 2007), 96.

32 No pictures of any of these historical MPLA figures are shown at the MAAN. 
of the MPLA. But not inserting Neto's life in his party's epoch misses an historical contextualisation that is much needed with regards to how the MAAN reproduces and narrates Neto's political growth, from a nationalist and party leader to president of Angola.

In her well known volume on 'dead-body politics', Katherine Verdery notes that by arresting the process of a person's bodily decay the temporality associated with a person can be altered, 'bringing him into the realm of the timeless or the sacred, like an icon. ${ }^{33}$ This iconic dimension dissociates the historical subject from the fluctuations of time and the vicissitudes of the nation. This is what is attempted at the MAAN, the sacralisation of a physical body that is political, but which dissociates the historical subject, Agostinho Neto, from the vicissitudes of the contemporary Angolan nation. Here lies the second reason for the invisibility of the MPLA in the MAAN.

Studying Angola's political economy after independence Christine Messiant contends that the turning point in the regime was a 'shift to clientelism', a period 'in the mid-eighties when the move towards a liberalisation of the economy was initiated without a concomitant change in the Marxist-Leninist political institutional framework. ${ }^{34}$ Messiant notes that it was around 1985 that Angola's political economy began to change, transitioning from a 'classic socialist form' to what she calls 'savage socialism', combining the 'dictatorship of the single party, the dollarization of the economy ... and the transition to a political economy of clientelism'. The new dispensation with JES and his cronies at the helm had 'rendered obsolete the ideological commitment hitherto required of party membership. ${ }^{35}$ The MPLA had become a platform for clientelism that 'fostered a rent-seeking elite. ${ }^{36}$

The MAAN was started in 1982 and interrupted between 1986/87, around the time of this political shift. While its information materials point to the political and military context of the civil conflict for this interruption, ${ }^{37}$ they obviously fail to note the change in economic organisation and political principle. In essence, after 1985 the regime's political economy changed dramatically. With presidential rule escaping the supervision of the MPLA's Political Bureau, a 'new liberalism enabled the nomenklatura to take advantage of their position massively to invest in the illegal market, ${ }^{38}$ fuelled by 'private appropriation of public assets and massive rentseeking ${ }^{39}$ in the mid-1980s. These changes in political economy and above all the use of the party for economic promotion and self-aggrandisement began creating tensions with those who had stood alongside Agostinho Neto and had been members of the Political Bureau. The old guard's political legacy was directly challenged in the

33 K. Verdery, The Political Lives of Dead Bodies. Reburial and Postsocialist Change, (New York: Columbia University Press, 1999), 33-35.

34 Messiant, 'The Mutation', 95.

35 Messiant, 'The Mutation', 97-98.

36 M. E. Ferreira, 'Angola: Conflict and Development, 1961-2002', The Economics of Peace and Security Journal, 1, 1, 2006, 25; see also C. Messiant, 'The Eduardo dos Santos Foundation: or, how Angola's Regime is Taking over Civil Society', African Affairs, 100, 2001, 287-309; R. S. de Oliveira, Magnificent and Beggar Land: Angola since the Civil War (London: C. Hurst \& Co. Ltd., 2015).

37 Ferreira states that by the second half of the 1970s more than a quarter of state budget was fuelling the war effort. By the 1980s sometimes more than 40 percent of the budget was used in defence, amounting to 14 percent of GDP in 1978,28 percent in 1986 and 20 percent in the early 1990s. See Ferreira, 'Angola', 25.

Ferreira, 'Angola', 26. 
MPLA's Second Congress in 1985 by the new dispensation of power, only six years after Neto's death. The case of Lúcio Lara, perhaps the MPLA leader most closely associated with Agostinho Neto, is indicative of this process. A video produced by $\mathrm{ATD}^{40}$ to celebrate Lara's $90^{\text {th }}$ birthday states that after an internal crisis in 1983 due to the illicit enrichment of party leaders, in the $2^{\text {nd }}$ Congress of the MPLA, Lara was elected to the Central Committee but not included in the Political Bureau. In that same situation were old companions like Ludy Kissassunda, Ambrósio Lukoki and Evaristo Kimba, all old supporters of Agostinho Neto. The video states that 'the ideals from the beginning of the struggle were being put aside and replaced by ideals with which Lara did not identify with.' In 1988 he would say in conversation, 'I had a thousand and one apparent reasons, apparent, to ask my demission from the party in a phase like this. ${ }^{31}$

The overturn of the previous elite and the setting aside of Neto's political values and legacy in the MPLA are crucial elements to explain the sidelining of the MPLA in the MAAN, a disassociation of Neto from the vicissitudes of the contemporary Angolan nation and most particularly its ruling party the MPLA. The reason for this politically charged aspect of representation making in the MAAN rests in the authorship of the narrative design. With the redesign of the project in 1998, Neto's family had a very significant participation in setting the interior narrative of the memorial. Besides several inputs and constant consultation, during this period Maria Eugénia Neto, Agostinho Neto's wife and President of the FAAN ${ }^{42}$, personally went to Pyongyang, accompanied by a team of Angolan technicians to oversee the work being developed by the MOP on the statues that would figure in the MAAN. ${ }^{43}$ While the authors were not able to conduct planned interviews with Maria Eugénia Neto, Irene Neto or any other member of Agostinho Neto's family, from how the MAAN sets its narrative, it became increasingly clear throughout research for this article that the shifting policies and ideologies of the 1980s, the aggrandisement of the figure and cult of personality of JES as the architect of peace in the 1990s and early 2000s, had broken a chain between Neto's family, the old struggle companions and the contemporary MPLA. This tension become a central feature in the singling out and elevating of Agostinho Neto while silencing the MPLA.

Nevertheless, the MAAN is undoubtedly a place of importance to the Angolan state, a bastion of official state memory visited by all foreign leaders arriving in the country, the place where presidential inaugurations take place and new foreign diplomats and dignitaries are taken. All these activities and events posit Agostinho Neto as the nucleus of the nation, a vivid representation and sanctification of the father of the nation, the liberator, but also the artist and visionary. Whether the Angolan state's endorsement of the MAAN as an historically important and politically relevant site

40 Associação Tchiweka de Documentação, Lúcio Lara - Trajectória de um Combatente.

41 https://www.youtube.com/watch?v=zkDX7zO3eXE. Lúcio Lara only came to abandon politics in 2008 due to health reasons.

42 Fundação António Agostinho Neto, the António Agostinho Neto Foundation.

43 Meeting with Maria Eugénia Neto at the António Agostinho Neto Foundation in Luanda, 8 November 2018. See also C. Ferreira, 'A Fundação Agostinho Neto, no 90. Aniversário do Fundador da Nação', Novo Jornal, 243, 12 September 2012. 
works as a mnemonic signifier able to create signification upon social memory is the matter addressed in the next section.

\section{The state, the povo and the MAAN}

Apart from the sporadic state event, the monument was planned to become a central piece in the daily homage Angolan society was to pay to Agostinho Neto, a link to the independence of Angola and the person responsible for having delivered it to the people. In laying the already mentioned first cornerstone in 1982, JES stated that,

the intention of our party in perpetuating the image of the Immortal Guide of the Angolan Revolution, Founder of the Nation and MPLA-Partido do Trabalho, is founded in the willingness to maintain unchanged, for the future followers of our revolutionary process, the figure of he who knew how to interpret the just anxieties of our people and position himself along the exigencies of our own history. ${ }^{44}$

The memorial presents itself as the main articulator of national memory, the place where the political body is intended to work as a body of a politics of foundation, nationalism and belonging, but also of timeless deference and intense sanctification. However, much like Stuart Hall asserted, the mere dissemination of a message does not assure its acceptance without a work of signification to project meaning. ${ }^{45}$ And in this, contrary to what the authors hypothesised, the MAAN is limited in scope as a signification instrument designed to create a sacred ground for the Angolan nation while propagating Neto's memory, surprisingly closing it to the public. It is here that Werbner's dynamics of elite memorialism begin to speak of state society relations in Angola.

The MAAN is in a part of Luanda that, although redeveloped, still holds very little traffic, which lessens any chance of popular pilgrimage to the site. It is located in a quiet place, one proper for a burial ground but not so desirable for the kind of lieux de mémoire it aims to be. The issue is not that the MAAN bars people from visiting. Like most public institutions it has come to reflect a tendency within Angolan society in recent history - the pushing of the margins outwards and the widening of the gap between the political system and the population. ${ }^{46}$ In an often authoritarian political system like Angola's where state security frequently shoots civilians for minor or no illegalities, it has become standard that ordinary people fear entering places like the MAAN, a monument with a magnitude that asserts awe and respect, protected and overlooked by an intruding police force.

\footnotetext{
44 JES's speech in 1982 after setting the cornerstone of the MAAN.

45 S. Hall, 'The Rediscovery of Ideology: The Return of the Repressed in Media Studies' in T. Bennett, J. Curran and M. Gurevitch (eds), Culture, Society and the Media, (London: Routledge, 1982) (e-book edition, 2005), 73.
}

See V. Martins, 'Politics of Power and Hierarchies of Citizenship in Angola', Citizenship Studies, 21, 2016, 100-15. 
Literature on state society relations in Angola, although with different outlooks, generally points to the existence of an authoritarian postcolonial elite of rent seekers maintaining a state system of clientelistic relationships by virtue of parallel and unofficial channels. ${ }^{47}$ Although more recent work has shed light into trade-offs and informal relations of dependency between the elites, state institutions and the population in the maintenance of this system, ${ }^{48}$ virtually all literature recognises the authoritarianism of the regime and the disenfranchisement of the ordinary population. Soares de Oliveira refers to the exclusion of the poor, a mindset that considers poverty unsightly and that has presided over the reorganisation of Luanda. ${ }^{49}$ It is exactly in those spaces where poverty is treated as a disease that the forbidden grounds for ordinary Angolans are found. Yet, as Martins argues, it is not so much exclusion as it is an oscillation that subjects ordinary Angolans between citizenship and marginalisation from it, leaving the majority of the population to live in a dispensation that frequently renders them disposable. ${ }^{50}$ This habitus informs those of lesser status of their social category and living space.

The MAAN does not escape the logics that divide the country between elites and ordinary population, echoing what Werbner termed elite memorialism, the division between chefes (bosses, those in power) and the povo. ${ }^{51}$ Besides the generic use of the term povo in Marxist-Leninist rhetoric, passing references that enmesh an ambiguous and opaque popular will in alleged support of a centralised state, the MAAN contains few references to the Angolan people. Little mention is made of their diverse cultures, linguistic idiosyncrasies, geographies, moral imaginaries or historical, political, social and economic hurdles, apart from brief references to colonial exploitation and liberation. As a product of a larger and diverse MPLA cosmology, it takes for granted the often repeated slogan 'o MPLA é o povo e o povo é o MPLA'. Yet, if even the MPLA is sidelined in the MAAN, where does that leave the povo?

The povo is ambiguously referenced throughout the MAAN. It is symbolically described as the ideological lever and motivator of the liberation struggle, the recipient of the gift of liberation and independence. It is exactly through this liberation that the povo appears, not in its varied historical experience but in the realisation of its full potential, depicted in images and statues showing healthy, young, confident and happy expressions. Always segmented in its relation to labour, the povo is defined as the professionals who will help Angola develop and reach its potential. This is seen in the hall of professions, an immense corridor with several statues depicting the povo as the teacher, the doctor, the peasant, the oil engineer or the geologist, amongst other representations.

See for example Messiant, 'The Eduardo dos Santos Foundation'; R. S. de Oliveira, 'Magnificent and Beggar Land'; D. Péclard, 'Introduction au Théme les Chemins de la "Reconversion Autoritaire" en Angola', Politique Africaine, 110, 2008; Martins, 'Politics of Power'; P. C. J. Faria, The Post-War Angola: Public Sphere, Political Regime and Democracy (Newcastle upon Tyne: Cambridge Scholars Publishing, 2013).

48 C. Gastrow, 'Cement Citizens: Housing, Demolition and Political Belonging in Luanda, Angola', Citizenship Studies, 21, 2, 2017, 230; J. Schubert, Working the System: A Political Ethnography of the New Angola (New York: Cornell University Press, 2017); S. Croese, 'Inside the Government, but Outside the Law: Residents' Committees, Public Authority and Twilight Governance in Post-War Angola', Journal of Southern African Studies, 41, 2, 2015.

49 de Oliveira, 'Magnificent and Beggar Land', 72.

50 Martins, 'Politics of Power'.

51 Werbner, 'Smoke from the Barrel of a Gun', 87. 


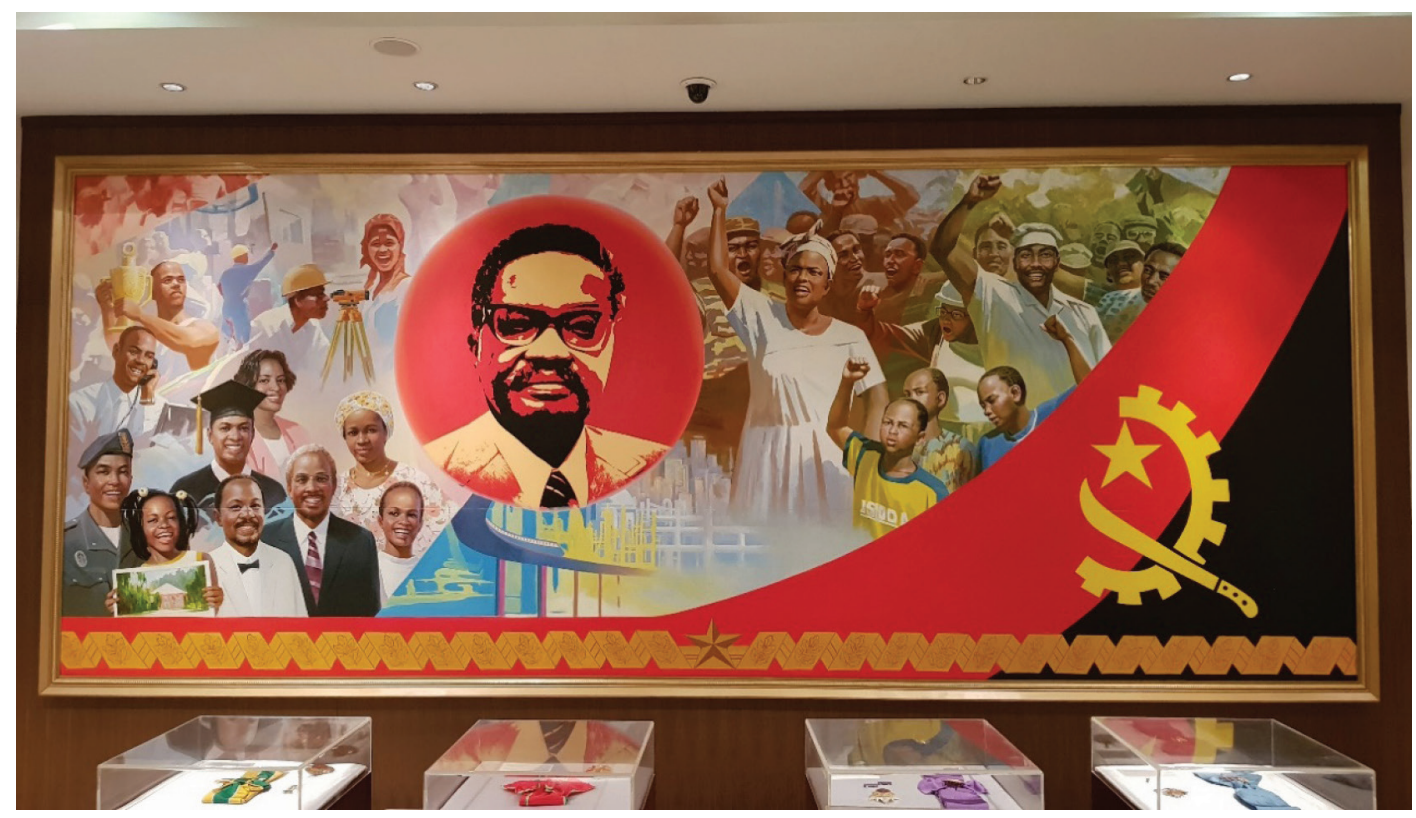

Figure 2: Large painting of Agostinho Neto with a representation of the Angolan people and national flag (Photograph by Vasco Martins - CROME)

But the povo referred to in the MAAN, while an attempt to be as comprehensively national as possible, is often considered to be the povo do governo, the people of the government, not the povo da UNITA, the people of UNITA or any other povo. ${ }^{52}$ People who historically supported and militated in other nationalist organisations than that of Neto's, the MPLA, point to the political leanings and partisan representations in the MAAN, as they do towards many other enterprises around the country. Yet, this does not mean the MAAN is open to MPLA supporters, the povo do governo. On the contrary, the MAAN is symbolically closed to any povo, regardless of urban or rural provenience or political standing. And it is so due to the structural idiosyncrasies of Angola: the place of the povo, by default poor, is to live at the margins of the Angolan state.

Rigoberto Fialho, the Director of the Department of the Sarcophagus, frames Angola's restrictive environment not as a structural issue but as a dilemma around a particular duality: on the one hand opening the monument for everyone to visit in a city with roughly 7 million people where the majority is essentially poor and carries imagined implications of sloppiness, of dirtying and disrespect or, on the other hand, trying to maintain a modicum of control to conserve the dignity and respect many believe it deserves. Fialho's dilemma mirrors the government's vision of creating

52 For the conceptualisation of povo do governo and povo da UNITA see J. Pearce, Political Identity and Conflict in Central Angola, 1975-2002 (New York: Cambridge University Press, 2015), 15. 
a new Luanda, ${ }^{53}$ a Dubai-like place where tourism and business pours masses of foreigners into the city, turning it into a locus where the invisible hand of capitalism would consequently lift Angolans from poverty. The MAAN is located in a part of Luanda that was organised to be a Political Administrative Centre ${ }^{54}$ and will continue to expand with the announced Bairro dos Ministérios, a place with 28 ministerial buildings and various other commodities for the ruling class. Yet, in this new Luanda the $z$ ungueiras ${ }^{55}$ cannot be seen in the streets, poor Angolans cannot be found picking food out of dumpsters and street children cannot be spotted harassing tourists and business people for their coins. As Soares de Oliveira mentions, poverty and the poor make for an unsightly view.

Fialho states that the sarcophagus room in particular is a place that demands respect and as such the public cannot disturb its dignity which the MAAN tries hard to maintain. When the MAAN was inaugurated, 'visits to the sarcophagus were limited', only 'scheduled to entities, with or without protocol. It was not very public. ${ }^{56}$ But because visitors felt the tour was incomplete without entering the room where the body of Agostinho Neto rests, the MAAN decided to make all visits public.

So it became open to all visitors, of course with a few restrictions because it is a space of conciliation, of respect, a space where we go to pay homage to the founder of the nation and first president of Angola. So we limit a bit in terms of the presentation of people [in terms of clothing]. In reality everyone can go. But we see how people are [presented]. It is basically the same as going to a cemetery. ${ }^{57}$

As noted, people must be presentable, that is, properly clothed. ${ }^{58}$ This in a country where the majority of the population wears t-shirts, flip flops or sneakers, or African cloths to cover their bodies, and possess no financial means to be as properly clothed as their fashionably presented elites. And while it is true that most memorials, museums and monuments around the world demand a certain etiquette, it is precisely because it is not adapted to the economic circumstances of its social environment, not to mention its political apparatus, that the impact the MAAN attempts to have upon Angolan social memory is curtailed. This enclosed environment has led people to question whether or not Neto's body truly is inside the casket. As Fialho explained, 'a few years ago there was speculation that the body was no longer there ... This information I heard in backroom talk, street talk. ${ }^{59}$

Neto's body was not always sealed. In fact, after embalming in Moscow, the body was put on public display at the provincial commissariat in Luanda, today the

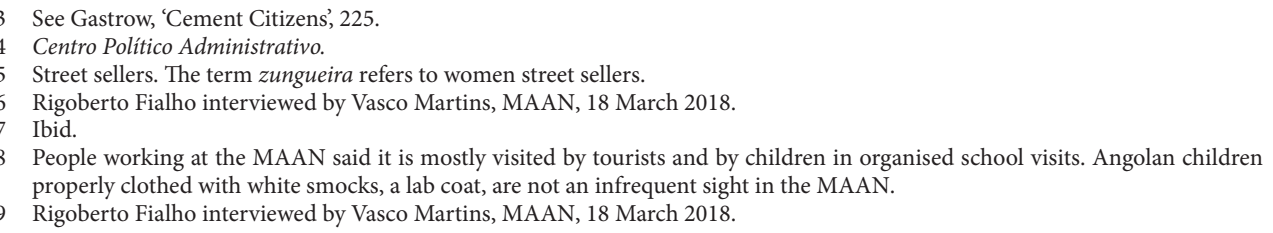


provincial government building adjacent to Mutamba. There Neto rested in a glass casket and his body was displayed for all Angolans who wished to visit and pay their final homage. But much like Lenin's, ${ }^{60}$ Neto's body required a series of treatments and maintenance ${ }^{61}$. Rigoberto says at the time the Angolan government was not in a financial position to allow the continuous treatment of the body in order for it to continue to be visible. The family also weighed on the decision to move Neto's body to a closed casket, as Rigoberto says it became painful for them to have the body in public display. Hence, the decision was made to move the body to a closed casket after which it was taken to the presidential palace and finally to the MAAN, Neto's final resting place. But the closing of Neto's casket ironically works as a metaphor for the historical closing of the state and nation to its population years after his death. The fact that Neto's body went from a public place in the heart of Luanda to the MAAN, far from the city's main axis, is indicative of the movement that separated both politically and geographically ordinary Angolans from Neto and the regime's elite. That the memorial was made the locus of official presidential visits by default further exacerbates and confirms this closed atmosphere. Under the direct tutelage of the Office of the Presidency of the Republic of Angola, as Rigoberto Fialho states, protocol maintains that foreign presidents visiting the country must pay homage to Agostinho Neto, usually characterised by a visit to the memorial and the deposit of a wreath of flowers upon Neto's tomb. Yet, this top level, highly controlled setting, heavy on both common police forces and presidential guards, creates an even more restrictive environment that works as a physical boundary around the memory of Neto, who has his remembrance constrained in a dignified, albeit informally closed area.

The MAAN clearly works as a symbolic reading of the parallel between the display of Neto's body and the recent political history of Angola. But as Werbner found in Zimbabwe, it also underlines the gap that has been progressively widening between the elites and the population. The instrumentalisation of history and memory for political purposes, the increased securitisation of life due to the past political and military circumstances of the country and the shifts in political economy that deepened inequality have contributed to create an abyssal rift between the population and an extremely rich and powerful elite. This socio-economic divide manifests in every detail of life in Angola. Since the MAAN is not immune to such logics, the political nation, symbolically represented in Neto's body, became hidden to the public, closed upon its centre without volunteering the peripheries, where the overwhelming majority of people are situated. The reigning notion that politics and the nation is not for Angolans to experience, but to respect and obey, has also left its mark upon the organisation and visiting logistics of the MAAN. The immediate consequences of this deep inequality and restrictive access is that the MAAN fails to become the

See A. Yurchak, 'Bodies of Lenin: the Hidden Science of Communist Sovereignty', Representations, 129, $2015,116-157$.

61 Rigoberto Fialho explained that a group of Russian medical doctors were treating Agostinho Neto's body so it could remain on display. 
centrepiece of dialogue it attempts to be in the ways Angolans continuously reimagine the past.

It became obvious during fieldwork that the people working at the MAAN consider Neto a man of great vision. Everyone the authors spoke to argued that his lessons are contemporary and provide solutions to problems Angola had in the past and will have in the future. Its central narrative is the famous saying 'what is important is to solve the problems of the people. Yet, the fact that the MAAN is inaccessible to many appears to defeat its purpose of influencing social memory and propagating Agostinho Neto's thought and vision for the country. Indeed, the porousness of the MAAN to the logics of the often predatory and marginalising Angolan state failed to include the exact people Neto mentioned, those who everyone at the MAAN feel would gain in knowing more about the first president of Angola. It is perhaps this contradiction that adds a dramatic flair to the monument's often empty halls.

\section{Conclusion}

Monuments are a crucial part of how nations remember and commemorate. Having achieved independence in the latter part of the $20^{\text {th }}$ century, southern African countries have not stopped debating colonialism and the postcolony. As these debates spill over to processes of memorialisation and monumentalisation of liberation struggles, they come to reflect historical divisions, different nationalist perspectives and postcolonial controversies. Monuments all over southern Africa echo these elements, most falling into what Werbner calls elite memorialism, a bias in memorialisation that promotes the role of elites, the struggle heroes, while silencing the povo. These monuments aim to constitute important devices in shaping public memory, providing interpretations that constitute particular readings of history. Yet, due to this exact bias in memorialisation, such monuments tend to leave large sections of society at the margins. As demonstrated in the article, the MAAN does not escape this tendency. On the contrary, it exposes two dimensions that contribute to this bias, grounded in the ruling party's many divisions and dissidences, and in the idiosyncrasies of Angola's postcolonial political and economic shifts. While describing the main mnemonic themes and narratives inscribed in the monument, the article analysed its political representations and silences while questioning its ability to become an active element in shaping social memory in Angola. In this, the article raised two main concerns. Firstly, by silencing the MPLA and Agostinho Neto's role as the president of the MPLA within its halls, the MAAN opted to advance the memory of Neto only as the president of Angola, forcing a narrative of solitude that silences the contributions of many MPLA leaders and militants while avoiding insertion in constellations of well-established liberation mnemonics. Secondly, the MAAN did not escape the hierarchies of power and social division that have come to define postcolonial Angola. As with most public institutions in Angola, the MAAN followed the same socio-economic logics that have defined Angolan society, particularly the marginalisation of the poor, the overwhelming majority of the Angolan population who have little to no access to the memorial due to its symbolic 
elitist apparatus. This has essentially closed the MAAN to a larger public, one that is avidly discussing new imaginaries of liberation and nationhood, a discussion the MAAN is not able to participate in exactly because of the dynamics that define state society relations in Angola. 